\title{
Biomethane Potential of Salicornia Sinus-Persica at Seawater Conditions
}

\author{
U. Javid, S. Almardeai, J.R. Bastidas-Oyanedel, and J.E. Schmidt* \\ Masdar Institute of Science and Technology Institute Centre for Energy-iEnergy, PO Box 54224, Abu Dhabi, United \\ Arab Emirates, Abu Dhabi - UAE
}

\begin{abstract}
It is essential to find alternatives to fresh water to produce biofuels in the UAE where the consumption per capita of water is almost double that of global consumption. This study uses a local halophyte plant Salicornia sinus-persica found in the arid region of the Emirate of Abu Dhabi. The objective of the work is to determine the biomethane potential using seawater as media and anaerobic sludge as inoculum. The experimental work was carried out in batch mode and Gas Chromatography was used to analyze the biomethane production. The results showed an increment of biomethane potential over a period of 48 days, the maximum value obtained was $22.12 \mathrm{mlCH}_{4} / \mathrm{gVS}$.
\end{abstract}

Keywords: Seawater, Biorefinery, Anaerobic Digestion, Biomethane Potential

\section{Introduction}

Salicornia sinus-persica has been identified by Akhani (Akhani, 2008) as a separate specie in the Persian Gulf region growing in the coastal region of the Emirates of Abu Dhabi (Cybulska et al., 2014). Utilizing Salicornia for biorefineries in arid regions could minimize the consumption of fresh water which is especially beneficial for the Emirates of Abu Dhabi where fresh water lacks and is produced through desalination (Bastidas-Oyanedel et al., 2015). UAE is among the top producers of desalinated seawater worldwide, where approximately 70 percent of the cost is to generate energy for desalination ("Pilot UAE desalination plants just months away from full operation | The National," n.d.). Our objective is to use seawater and sludge from Al Wathba wastewater treatment plant to determine the biomethane potential of Salicornia sinus-persica.

\section{Materials and Method}

In this experiment Salicornia sinus-persica was used as substrate, seawater as media, and anaerobic sludge as inoculum. The sample was first air dried and milled following by characterization $\mathrm{f}$ or TS, VS and ash content. Sample was provided by Prof. M.H. Thomsen and her team (Masdar Institute of Science and Technology, Abu Dhabi). Seawater was sampled from Ras Alkhaimah and the anaerobic sludge was sampled from $\mathrm{Al}$ Wathba wastewater treatment plant, $\mathrm{Abu}$ Dhabi. Seawater $\mathrm{pH}$ was measured using commercially available probes.

Seawater salinity was determined by measuring the weight of salt after drying a known mass of sample at $150^{\circ} \mathrm{C}$ and $570^{\circ} \mathrm{C}$. The total solids (TS) and volatile solids (VS) of Salicornia sinus-persica and the anaerobic sludge was determined at $150^{\circ} \mathrm{C}$ and $570^{\circ} \mathrm{C}$. Biomethane potential experiments were conducted at $37^{\circ} \mathrm{C}$ in serum bottles with $115 \mathrm{ml}$ liquid volume and $212 \mathrm{ml}$ headspace. The experiment was conducted using $1.09 \mathrm{gVSsalicornia} / \mathrm{gVSs}$ ludge and an inoculum of $11.4 \mathrm{~g}$. The biomethane produced was measured by gas chromatography.

\section{Results and Discussion}

Seawater salinity was $43.2 \pm 0.1 \mathrm{~g} / \mathrm{kg}$ and a $\mathrm{pH}$ was $7.29 \pm$ 0.03. The air-dry Salicornia sinus-persica VS was 0.72 $\mathrm{gVS} / \mathrm{g}$ _original_sample and TS was 0.91 gTS/g_original_sample. The inoculum, anaerobic sludge VS was $1.3 \pm 0.01 \mathrm{gVS} / \mathrm{g}$ _original_sample and the TS was 0.02 gTS/g original sample. Through a period of forty eight days the samples were kept in incubation at $37 \mathrm{C}$. Gas chromatography analysis at regular intervals showed an increment in the biomethane production over the incubation period.

${ }^{*}$ Corresponding author E-mail: jschmidt@ masdar.ac.ae 
Figure 1 shows the biomethane potential of Salicornia sinuspersica under seawater conditions using anaerobic sludge as inoculum. The ideal theoretical value of biomethane potential per gram VS, $370 \mathrm{mlCH}_{4}$ was not obtained due to the addition of anaerobic sludge. The anaerobic sludge is not accustomed to the high salinity in Abu Dhabi seawater. However, the results obtained are promising proving the system has a significant potential for biomehtane production. From the beginning the experimented system showed a constant increment.

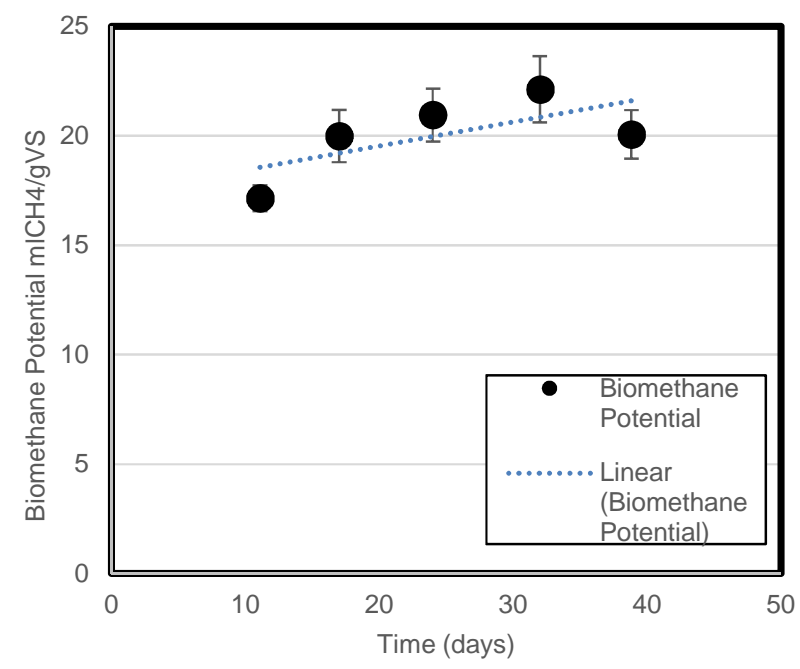

Figure 1 Biomethane Potential of Salicornia Sinus-Persica at Seawater Conditions with Anaerobic Sludge over an Incubation Period of 48 Days. Seawater, 43.2 G/Kg Salinity. The Substrate over Inoculum is 1.09gvs Salicornia Sinus-Persica /Gvsinoculm.

The present work has showed, the use of sea water is possible in the production of biomethane using anaerobic sludge. This work has shown the potential of producing biofuels and chemicals using local crops and seawater from the Emirates of
Abu Dhabi. Not only does this opens up opportunity for further research into biofuel production in the United Arab Emirates but also in other arid regions in Africa, India and Pakistan. It is of utmost importance economically and environmentally for UAE to substitute sea water instead of fresh water where the individual consumption of water is $550 \mathrm{~L}$ per day which is almost twice the global average consumption of $250 \mathrm{~L}$ per individual per day ("Conserving every drop | EMS," n.d.). The use of sea water in the UAE can help lower the individual consumption of fresh water, as well as lowering the production cost of alternative energy using Salicornia sinus-persica as biomass which is a local crop and highly adaptive to the regions climate.

\section{References}

[1] Akhani, H., 2008. Taxonomic Revision of the Genus Salicornia L . ( Chenopodiaceae ) in Central and Southern Iran. Pakistan J. Bot. 40, 1635-1655.

[2] Conserving every drop | EMS [WWW Document], n.d. URL http://ems-int.com/blog/conserving-every-drop/ (accessed 10.30.15).

[3] Cybulska, I., Brudecki, G., Alassali, A., Thomsen, M., Jed Brown, J., 2014. Phytochemical composition of some common coastal halophytes of the United Arab Emirates. Emirates J. Food Agric. 26, 1046-1056. doi:10.9755/ejfa.v26i12.19104

[4] Pilot UAE desalination plants just months away from full operation | The National [WWW Document], n.d. URL http://www.thenational.ae/uae/environment/pilot-uaedesalination-plants-just-months-away-from-full-operation (accessed 10.30.15).

[5] J.R. Bastidas-Oyandel, S. Al-Boainain, S. Almardeai, J.E. Schmidt, 2015. Seawater biorefinery of Salicornia sinuspersica - biomehtane potential at seawater conditions. AD14 Conference paper, Viña del Mar, Chile. 